\title{
A century of research on the Peu-Richardien
}

\author{
CHRIS SCARRE
}

\begin{abstract}
Baron Eschasseriaux's discovery of the ditched neolithic settlement of Peu-Richard in 1882 was a turning point in the study of west French prehistory. Chris Scarre here reviews the progress that has been made since that initial investigation and suggests how the 'Peu-Richardien' and the ditched camps of the third millennium $B C$ might be interpreted in social and economic terms. Dr Scarre has been carrying out research and excavation in this part of France since 1978, and is editor of the recent survey 'Ancient France 6000-2000 BC'.
\end{abstract}

HISTORY OF RESEARCH

Peu-Richard is the name of a low hill in rolling chalkland overlooking the marshland which has formed where the River Seugne meets the River Charente, a little way to the south of Saintes. It was here in 1882 that a farm labourer came across traces of a fortified enclosure rich in prehistoric material. The landowner, Baron Eschasseriaux, was an amateur archaeologist and when told of the discovery immediately arranged an excavation. A total of 106 trenches was opened in the course of this work, and a good idea of the complexity of the site layout, with its multiple ditches, was obtained (FIG. I). A recent aerial photograph has contributed some further details (PL. va). Eschasseriaux described the discovery of rock-cut ditches, remains of stone ramparts and traces of gateways. Potsherds, animal bones and flints were collected in abundance and some examples were illustrated in the report, though few details were given (Eschasseriaux, 1882). This material included quantities of decorated sherds of the type which came to be known as 'Peu-Richardien'.

The discoveries at Peu-Richard made a great impression on the French prehistorians of the day. Gabriel de Mortillet was so struck by the richness of the site that he toyed with the idea of adopting 'Peu-Richardien' in place of 'Robenhausien' as the term for the neolithic section of his prehistoric sequence, though fortunately nothing came of this. The visitor to the site today cannot fail to notice the quantities of worked flint and pottery which the plough continues to turn up. Peu-Richard was not, in fact, the first site to yield pottery of the type to which it eventually gave its name. That honour must go to a burial mound at Availles-sur-Chizé, excavated by Arnauld and Phiolleau in 186r, though the excavation was inadequately published and the discovery of the decorated pottery received little notice at the time (Burnez, 1976 ( 1962$), 15$; Germond 1980,30 ). Peu-Richard was however the first of the impressive fortified sites of the region to be investigated, and it was here that the two leading features of the Late Neolithic of maritime WestCentral France were found together for the first time-the ditched enclosures (FIGS. 3-5) and the flamboyantly decorated pottery (FIG. 6). Thus it is with some justice that it came to be regarded as the 'type-site'.

The interest aroused by the discovery of PeuRichard led to the search in the Saintes area for other sites of this kind, and three more PeuRichardien enclosures were found and investigated in the course of the following zo years--Moulin-deVent (1882-3), Chaillot-de-la-Jard (1889), and Mourez-de-Berneuil (1893) (Clouet I928; Burnez \& Morel, 1965). The excavations carried out at these sites greatly increased the amount of PeuRichardien material available for study. All these early investigations were in the same limited area, however, and the wide distribution of PeuRichardien material and the regional differences in the pottery decoration did not become apparent until later.

No further Late Neolithic fortified sites were discovered until after the Second World War. In the I950s, Burnez began an intensive search for neolithic remains in the area known as the Cognaçais, east of Saintes and south of the River Charente. 


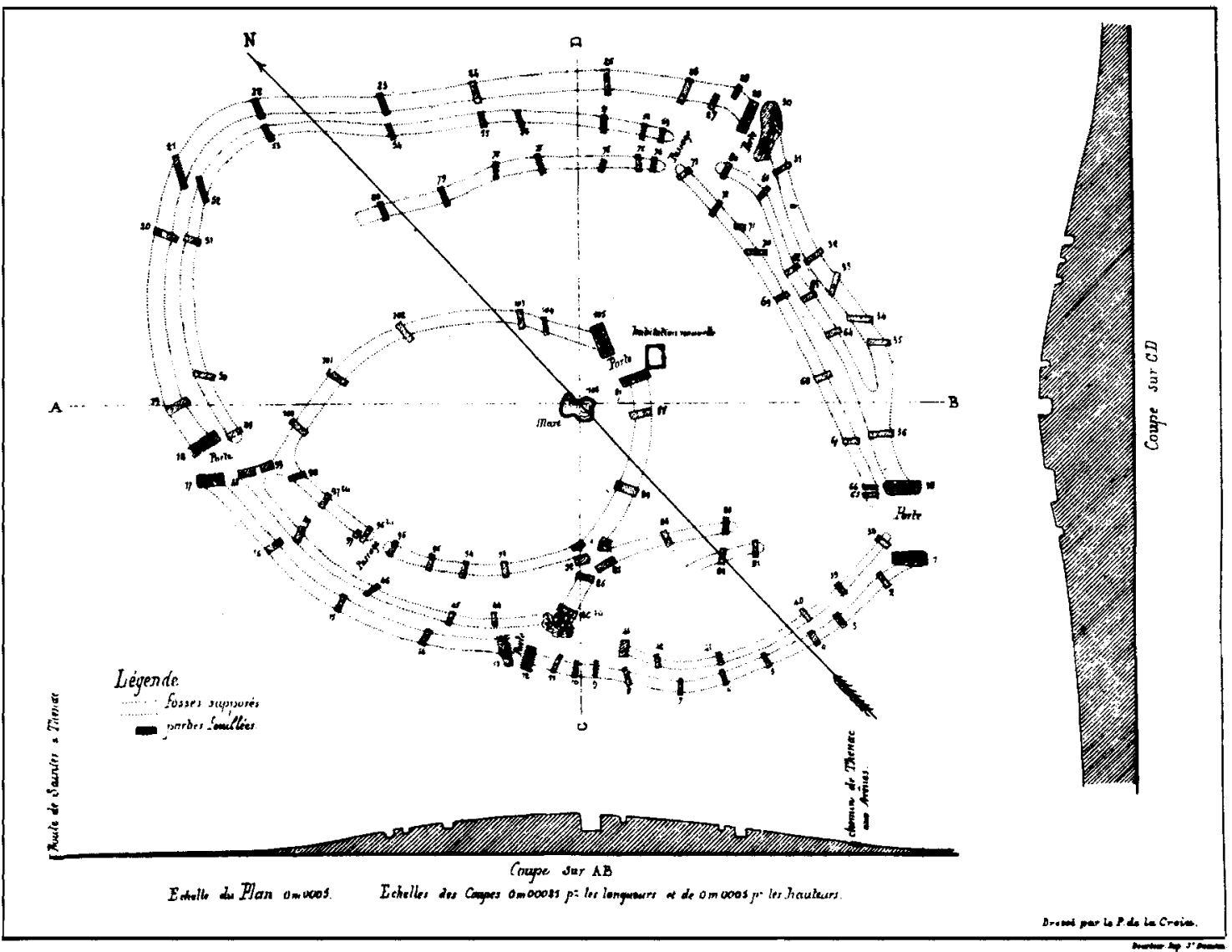

His efforts were rewarded by the discovery of ten or eleven new Peu-Richardien sites, where none had been known previously. Burnez carried out excavations, either alone or in collaboration with others, at several of these (Les Matignons: Burnez \& Case 1966; Soubérac: Burnez 1965; Le Brandard de Montagan: Guillien 1968, 316; Biard: results unpublished), and was able to show that all had had enclosing ditches or ramparts. The results of this work formed the basis of his important synthesis $L e$ Néolithique et le Chalcolithique dans le CentreOuest de la France which was completed in 1962 , but not published until 1976 . Burnez's investigations extended the geographical range of known Peu-Richardien sites and revealed the existence of a new style of Peu-Richardien pottery decoration (the 'Moulin-de-Vent' style), which appeared to be restricted to the Cognaçais. He attempted to explain the origin of the flamboyant pottery, the co-existence of the Saintonge and Moulin-de-Vent styles, and their close association with the fortified sites by means of an invasion hypothesis which will be discussed below. Another notable feature of Burnez's work on the fortified sites of the Cognaçais was his use of aerial photography to back up the results of fieldwalking and excavation (Burnez \& Façon, I 957; Burnez \& Case, I 966).

The late 1950 s and early i 960 s saw the discovery of Peu-Richardien material also on the north-east coast of the Gironde, notably at Semussac (ChezReine), Barzan and L'Eguille (Colle, I957; 1965). Here again subsequent aerial photography has clarified the form of the complex enclosures (Dassié, I978, photos 4I, 48), and at Chez-Reine an important campaign of excavation was carried out between 1965 and 197 I Mohen 1967; 1973; Bergougnan \& Mohen, ig80). In the same period investigations and excavations to the south, in the 
Libourne area of Gironde, revealed a further regional variant of Peu-Richardien decorated ware, the 'Roanne' style (PL. $\mathrm{v} b$ ), though only one fortified site which can be associated with this has yet been found (Coffyn 1960; 1965; Coffyn \& Ducasse, 1962).

The decade starting in $197 \mathrm{I}$ constituted the third major period of discovery of new Peu-Richardien sites, and the present pattern of distribution (FIG. 2) is largely the result of this. The new discoveries in this decade were the product of campaigns of aerial survey and photography conducted by Dassié in Saintonge and by Marsac in the Marais Poitevin area (Dassié, I978; Marsac \& Scarre, I979; Scarre, I 980 ). Two-thirds of the known fortified sites were discovered by these campaigns, and new sites were found, not only in areas where fortified settlements were already known to be present, but also as far north as the southern edge of the Armorican Massif. Several small excavations followed this spate of new discoveries, but special mention must be reserved for the extensive campaign being conducted by Joussaume at Champ Durand (Vendée), where work began in 1975 and is expected to continue for several more years. This large-scale project has already greatly increased our knowledge of the Peu-Richardien fortified sites (Joussaume 1980; 1981).

Peu-Richardien pottery has been found principally at the fortified sites and relatively rarely at other types of settlement, while very few of the fortified sites which have been investigated have failed to yield material of this type. It is, however, preferable to restrict the use of the term 'PeuRichardien' to the decorated ware and the sites on which it is found, since the fortified sites have occasionally yielded other types of decorated pottery and to class them all as Peu-Richardien would therefore be misleading.

In the discussion which follows, the fortified sites and the pottery will first be treated separately, and then recombined in order to consider what kind of phenomenon they may together have represented.

\section{THE FORTIFIED SITES}

Ditched enclosures of neolithic date have been found in various parts of Western Europe, but few have such evidence for fortification as those of West-Central France. There are some 60 sites of this type in the region (FIG. 2), 40 having been discovered within the last ro years as a result of the aerial survey and photography referred to earlier.

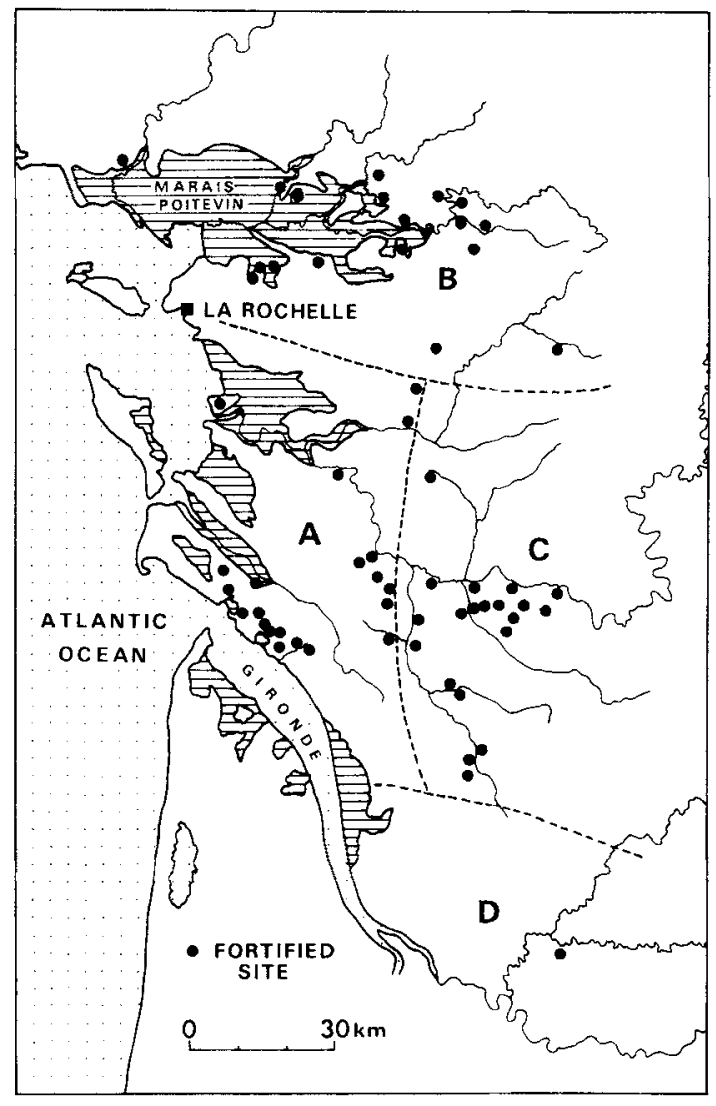

Fig. 2. Distribution of late neolithic fortified settlements and Peu-Richardien decorated pottery in West-Central France. The broken lines demarcate the areas of the four Peu-Richardien decorated pottery varieties: A, Saintonge; B, Poitou; C, Moulin-de-Vent; D, Roanne. Shaded areas are coastal marshlands

The aerial photographs show that there is a considerable degree of variation in the plan of the defences. This variability raises the possibility that not all are of late neolithic date, though none has yet been shown to belong to an earlier or later period.

The form of the entrances allows the fortified sites to be divided into two classes, and this is a particularly useful classification since it can be applied to sites known only from aerial photographs. The first group consists of sites with simple entrance-gaps, while the members of the second have entrances furnished with outworks of the 'pince de crabe' or 'crab's pincers' type (FIGs. 3-5). The recent aerial photograph of Peu-Richard (PL. va) shows that it belongs to the 'pince de crabe' 
group, a fact not recognized by the early excavators. The 'pince de crabe' category is in fact the more numerous. The excavations at Les Matignons revealed ditches of considerable proportions, up to $4 \mathrm{~m}$ wide and $2 \mathrm{~m}$ deep, cut into the bedrock (Burnez \& Case, I966). At Champ Durand the inner ditch was $2.5 \mathrm{~m}$ deep and $5 \mathrm{~m}$ across at the mouth (Joussaume, I980). These substantial ditches were backed by dry-stone ramparts, the material for which was probably quarried from the ditches. In one or two cases it seems that owing to the hardness of the bedrock no ditch was dug, the defences then consisting of a rampart alone. Such seems to have been the situation at Soubérac, where the remains of a particularly fine rampart were discovered (Burnez, 1965). There may be many more sites with rampart but no ditch still to be found, since they do not show up so well on aerial photographs and hence are much more difficult to discover than ditched sites.

Radiocarbon dates and pottery suggest that some of the fortified settlements may have been occupied for a period of almost half a millennium, though of course not all need have been in use for this long. In a number of cases alterations or additions appear to have been made to the defensive works during the occupation. At L'Angle on the southern edge of the Marais Poitevin one of the two original pince de crabe' entrance-works seems to have been blocked at some stage so as to form a semi-circular bastion (but see Joussaume, 1981,297 , for a slightly different view). The pottery from the ditches of Chez-Reine (Semussac) (FIG. 3) suggested a span of occupation lasting several centuries, with the central circular double-ditched enclosure being earliest, later considerably elaborated by the addition of a complex system of entrance-works and outworks (Mohen, I 973). The conversion of the original modest northern entrance-work at this site into an elaborate example of the 'pince de crabe' type suggests that the latter is a later form than the simple entrance-gap, and that in some cases 'pince de crabe' entrance-works may have been added to existing circuits. Where a site has more than one circuit of defences, these need not all have been contemporary. At Champ Durand (FIG. 4) decorated pottery of earlier Peu-Richardien type came only from the two inner ditches; the outer ditch may be a later addition (Joussaume, I98I, 268). Finally, both at Mourez-de-Berneuil and at Les Matignons (FIG. 5) there were two intersecting double-ditched enclosures, which clearly could not

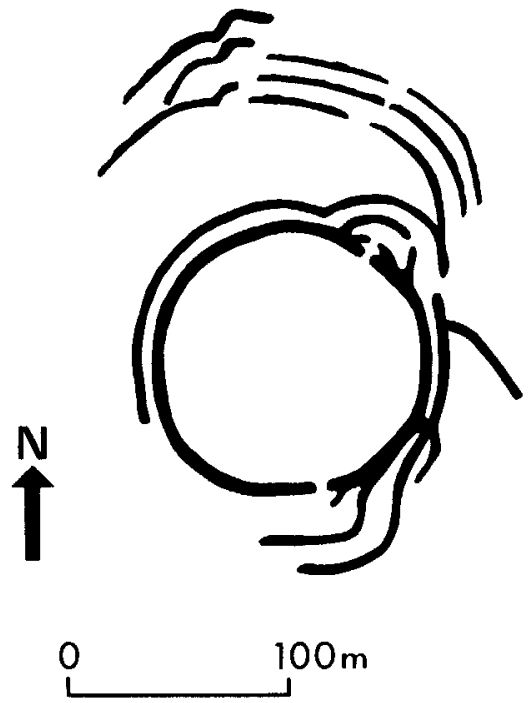

Fig. 3. The late neolithic fortified settlement of Chez-Reine at Semussac (Charente-Maritime) as revealed by aerial photography. The complex entrance works and outworks make this site particularly notable (after Mohen, 1973)

have been in use at the same time. Excavations at Les Matignons recovered pottery of the earlier 'Matignons' type from one, and of the later 'Moulin-de-Vent' type from the other (Burnez \& Case, 1966).

The evidence from within the defences of these sites is poor, since most are on chalk or limestone bedrock with thin soil cover, where repeated ploughing has removed all traces of any structures and has disturbed, destroyed or scattered the artifactual material. It is for this reason that the current excavation at Champ Durand has so far been unsuccessful in locating traces of structures, though abundant remains of domestic activities have been recovered (Joussaume, $198 \mathrm{I}$ ). It is partly also for this reason that recent excavations have tended to concentrate on the ditches of these enclosures, where greater depths of deposit are present. Even in the ditches, however, satisfactory sequences of stratified remains are rarely to be found, since repeated cleaning and recutting have resulted in material of different periods being mixed together in the same layers. This has seriously hindered the study of the development of the Peu-Richardien pottery styles, and it is to be hoped that in future more effort will be made to excavate sites with deeper deposits. The most reliable stratified pottery sequences so far dis- 


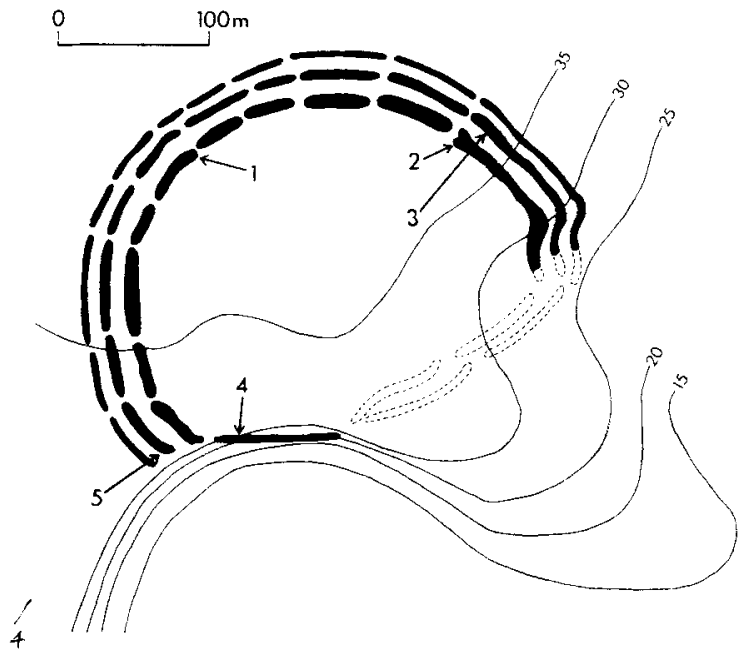

Fig. 4. Champ Durand (Nieul-sur-l'Autize, Vendée), the most thoroughly investigated of the neolithic enclosures of West-Central France. The site lies on the edge of the Vallée des Maléons, whose steep slopes allow the defences on the southern side to be reduced to a single length of ditch. A substantial dry-stone rampart is thought to have stood on the inner edge of each of the circuits of ditch, and in at least two places (1 and 2) remains, probably of dry-stone towers, were encountered. Two double burials ( 3 and 4), and one single burial (5), were recovered from the bottoms of the ditches. The existence of the double length of ditch closing the circuit on the south east has still to be verified by excavation. (After foussaume, 1981)

covered is from the apparently unenclosed PeuRichardien settlement of La Sauzaie, near the mouth of the River Charente (Pautreau, et al., 1974).

The available evidence suggests that the fortified sites were settlements, perhaps defended villages or the seats of local rulers. Their size (up to 8 to 9 ha in some cases, though smaller examples of about $\mathrm{I}$ ha are also known) indicates that they might have been substantial centres of population, containing the dwellings of perhaps as many as 2,000 people in the larger cases. We may however envisage parts of their interiors being given over to craft areas or stock pens. These sites also appear to have had a subsidiary function in respect of the disposal of the dead. Eschasseriaux at Peu-Richard and Deschamps at Mourez-de-Berneuil noted the presence of human skeletal material in the ditches, and several human bones, principally but not solely skull fragments, came from the outer and inner ditches of both enclosures at Les Matignons (Eschasseriaux,

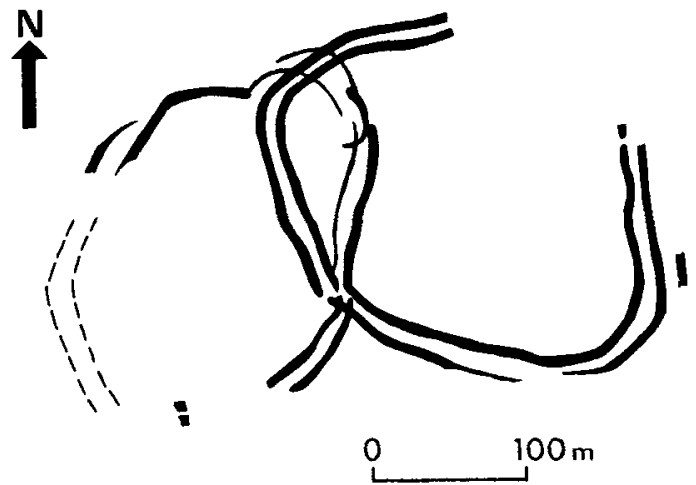

Fig. 5. Les Matignons (Fuillac-le-Coq, Charente). The two double-ditched enclosures as revealed by air photography and verified by resistivity survey and excavation. (After Burnez $\mathscr{6}^{\circ}$ Case, 1966)

I884; Burnez \& Morel, 1965; Burnez \& Case, 1966). The most impressive discoveries of this kind are, however, the five complete or nearly complete skeletons found in three different places in the ditches of Champ Durand (FIG. 4). It is clear that they had not been simply dumped in the ditches, nor did they seem to have arrived there through accident or as a result of hostilities. Some of the bodies were accompanied by grave goods and all appeared to be intentional deposits (Joussaume, I98I; Bresson \& Gadé, 1980). The evidence is, however, insufficient to suggest that burial was anything more than a secondary use of these sites.

The presence of human remains in the ditches is one of the features which links the neolithic enclosures of West-Central France with those of other parts of Western Europe such as southern Britain (e.g. Hambledon Hill: Mercer, 1980, Offham Hill: Drewett, I977) and north-eastern France (e.g. Menneville: U.R.A. I2, 1977). The WestFrench enclosures seem, however, to be later in date than the other groups and the common features are not, overall, very striking. It is possible that all the groups belong to a single family ultimately derived from the late bandkeramik enclosures of the Rhineland, but such an origintracing exercise is not of great value since it tells us little about the real nature and function of these sites in their different regional and local contexts. It was in particular local circumstances, and in response to a particular local need, that the fortified sites of West-Central France came into being, and it is at this level that their origin is best to be understood (Scarre, $1982 ; 1983$ ). 


\section{PEU-RICHARDIEN POTTERY}

The present evidence suggests that Peu-Richardien decorated pottery falls into four regional styles, in two of which an earlier and a later phase may be distinguished (FIGS. 2, 6; PL. vb). The decorated pottery at the sites investigated in the Saintes area late last century was principally of what may be called the 'Saintonge' variety, characterized by a decoration of paired incised or channelled lines forming wave, zigzag and oculi motifs, and by the decorated 'anses tunnelées' (FIG. 6:I). Only a single type of Peu-Richardien pottery was recognized as late as 1953, when Riquet suggested, on the basis of the predominantly coastally-oriented distribution and the lack of obvious local antecedents, that it must have been a foreign introduction. Riquet's judgement proved premature, however, as Burnez during the following few years discovered PeuRichardien pottery at a group of sites in the Cognaçais, much further inland. The pottery found at these inland sites was different from that of the Saintonge area and Burnez realized that it was a distinct regional variety, which he named 'Moulinde-Vent'. Its decorative motifs are broadly similar to those of the Saintonge Peu-Richardien, but are formed by applied relief lines rather than by incision or channelling, and the decorated 'anses tunnelées' are absent. Though Burnez's discoveries in the Cognaçais ended the coastal orientation of the Peu-Richardien distribution, he continued to support the hypothesis of a foreign derivation which Riquet had put forward earlier, and indeed developed this into a full-scale invasion model. Like other workers Burnez was influenced by the apparent similarity between the oculi motifs of the Saintonge Peu-Richardien and the Symbolkeramik of Los Millares, though he was careful not to be too precise about the origin of his invaders. The fortified sites from which so much of the Peu-Richardien pottery came were, in his view, to be interpreted as the settlements of the newcomers, fortified against the hostile indigenes, and this impression of an embattled intrusive populace was reinforced by the relative rarity with which Peu-Richardien pottery is found at other kinds of settlement site. The model was further elaborated to include an explanation of the Moulin-de-Vent style of the Cognaçais. Burnez asserted (though with no good evidence) that this style must have been later than the Saintonge Peu-Richardien. The latter he saw as the 'pure' style of the original invaders, while the Moulin-deVent must have arisen through the mixing with this of elements of the prevailing indigenous non-PeuRichardien ceramic tradition known as the 'Matignons' group. The technique of applied relief decoration is common to both Matignons and Moulin-de-Vent groups. It was not always made clear in Burnez's model whether the Moulin-deVent group was the result of the progressive adoption of indigenous traits by the invaders as they pushed their way inland, or of the adoption of Peu-Richardien traits by the indigenes (Burnez, 1956; 1976 (1962), 217).

It is not, perhaps, surprising that within the last decade new discoveries and a changed outlook have led to a rather different picture of the origins and development of the Peu-Richardien pottery styles. Burnez was writing at a time when invasion hypotheses were the height of fashion in archaeological circles, and allowances should be made for this when evaluating his theory. Some comments have already been made about similarities between Moulin-de-Vent type pottery and that of the Matignons groups. It was Burnez's own researches which led to the discovery of the Matignons group, and pottery of this type is now known not only from sites in the Cognaçais but also in Saintonge and around the Marais Poitevin, and everywhere appears as the precursor of the Peu-Richardien. Matignons sherds are the earliest pottery at several of the fortified sites. The technique of decoration, using applied strips of clay to form relief lines, is the same as that used on Peu-Richardien pottery of the Moulin-de-Vent type, though the motifs are much simpler (normally single vertical or horizontal lines). The Matignons ceramic assemblage contains some middle neolithic types alongside late neolithic forms, and is therefore best seen as a local development. It is reasonable to suppose that the Moulin-de-Vent style developed from this, at the same time borrowing motifs from the Saintonge Peu-Richardien.

A local origin can now also be argued for the Saintonge Peu-Richardien. As long ago as 1953, Nougier showed the oculi motifs to be not evidence of a derivation from the Symbolkeramik of Los Millares, the Ozieri pottery of Sardinia, or some other Mediterranean source, but a local adaptation of decoration to suit the shape of the popular 'anse tunnelée'. The carrying of incised lines around the paired circular openings of the 'anse tunnelée' would have given rise naturally to the oculi motif (FIG. 6:I). Recent excavations at La Sauzaie revealed an assemblage stratified below levels of 
classic Saintonge Peu-Richardien in which decoration consisted simply of single or paired incised lines running horizontally around the belly of the pot (Pautreau, et al., 1974). This assemblage is probably the immediate ancestor of the Saintonge Peu-Richardien and since there is no need to derive it from outside, it seems that the development of the Saintonge Peu-Richardien must, like that of the Moulin-de-Vent style, have been a local phenomenon. The arguments for a foreign origin of the Peu-Richardien, never very convincing, may now therefore be laid to rest.

Only two of the four Peu-Richardien regional pottery styles have so far been mentioned, and nothing has been said about chronology. The Roanne style of the Gironde area is similar to the Moulin-de-Vent style of the Cognaçais, applied relief decoration predominating (PL, vb). For neither of these groups is there sufficient dating evidence to support a scheme of internal development or phasing, and only one reliable radiocarbon date $(c .2400 \mathrm{bc}$, from the site of Biard in the Cognaçais) can be cited. The Matignons group which is thought to have preceded and perhaps given rise to the Moulin-de-Vent group has radiocarbon dates of between $c .2800 \mathrm{bc}$ and $c .2500 \mathrm{bc}$ (see table, p. 23, for details of these dates).

The Saintonge Peu-Richardien and the Poitou variant are both characterized by an early phase with incised or channelled decoration and 'anses tunnelées'. In both a later phase can also be distinguished. At La Sauzaie, early Saintonge Peu-Richardien is overlain by levels in which incised decoration becomes less common and motifs simpler. At the same time, 'anses tunnelées' disappear and relief decoration becomes predominant, though with simpler designs than in the Moulin-de-Vent or Roanne variants (Pautreau, et al., 1974). The early phase of the Saintonge Peu-Richardien may tentatively be dated (see table) to between $2600 \mathrm{bc}$ and $2500 \mathrm{bc}$, while for the latter phase there are radiocarbon dates of from $c .2500$ bc to perhaps 2100 bc. There are no dates for the later phase of the Poitou Peu-Richardien, but it is marked by the disappearance of 'anses tunnelées', a decline in the amount of decorated pottery so that plain ware becomes heavily predominant, and the absence of relief decoration (Joussaume, I98I, $35^{6-65}$ ). (There is a late radiocarbon date of 2160 be from Champ Durand (Joussaume, op. cit.) but it is unclear how this relates to Poitou PeuRichardien material.)
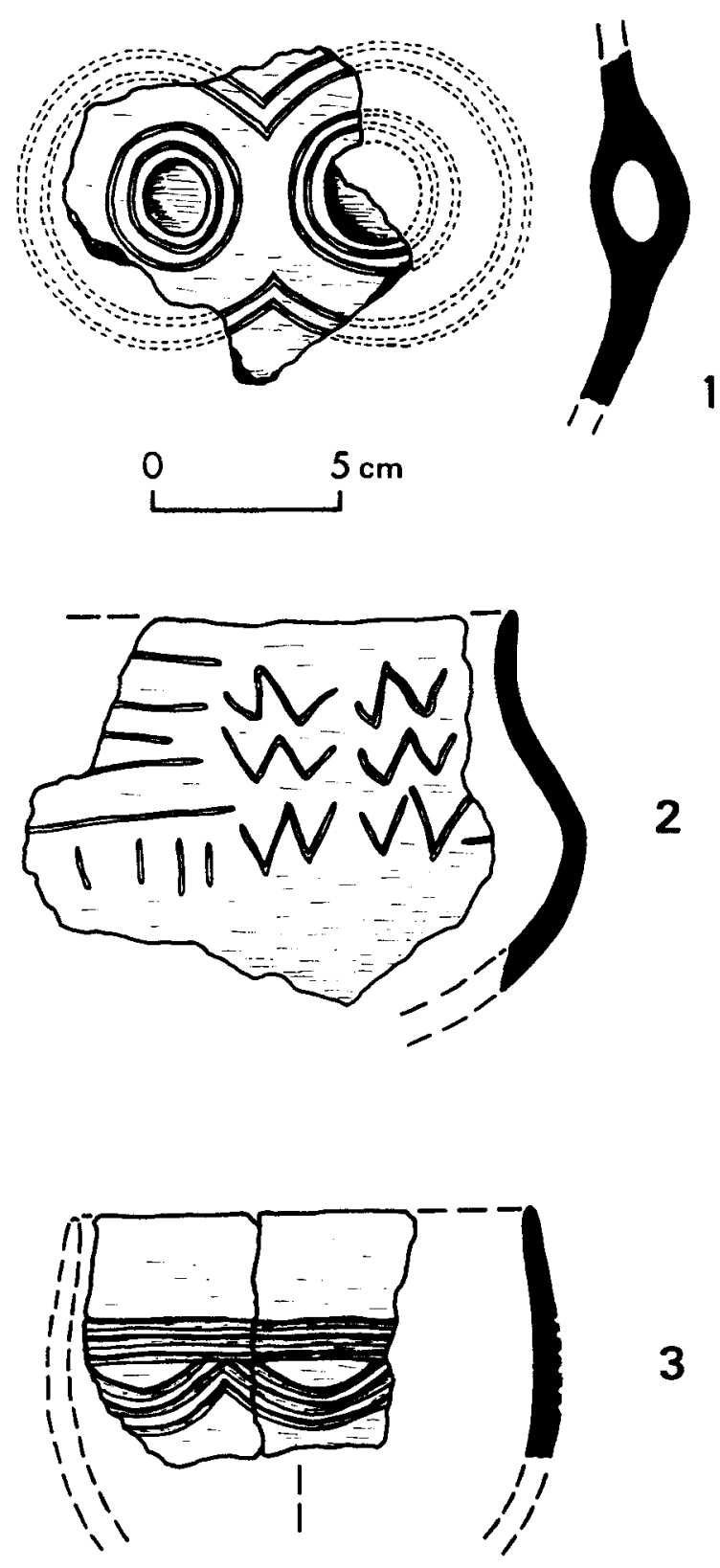

Fig. 6. Peu-Richardien pottery of the Saintonge and Poitou varieties with incised and channelled decoration. 1: 'Anse tunnelée' from Champ Durand (Vieul-surl'Autize, Vendée); 2: Decorated vessel from the burial mound of Availles-sur-Chizé (Deux-Sèvres); 3: Decorated vessel from the open settlement of Ors (lle-d'Oléron, Charente-Maritime). (1: after Joussaume, 1980; 2: now in Musée du Pilori, Niort; 3: in Musée Fleuriau, La Rochelle) 
The decorated ware is of course only one element in these assemblages; in addition, there are various coarse wares, polished stone axes, flint scrapers and trapezoidal tranchet arrowheads, bone points and other material. None of these, however, is exclusively associated with Peu-Richardien decorated ware and it would therefore be misleading to refer to them as 'Peu-Richardien' types.

\section{BURIAL SITES}

Three types of burial deposit have yielded decorated Peu-Richardien pottery. The burials in the ditches of the fortified sites have already been mentioned. Peu-Richardien decorated ware has also been found in a dozen or so megalithic tombs, though these are all cases of the re-use of an existing monument. A handful of burials in shallow graves, notably the double burial at Les Châtelliers-duVieil-Auzay (Joussaume, I98I, 365-8) have also been attributed to the Peu-Richardien, but not always on very good grounds. More interesting is a group of longs tumulus in the Marais Poitevin area, with a similar distribution pattern to that of the late neolithic fortified sites; present evidence suggests, however, that they are of middle neolithic date (Joussaume, I 98 I, 21 I-29, 244-5; Marsac, Riley \& Scarre, 1982).

\section{DISCUSSION}

To explain a flamboyant pottery style such as the Peu-Richardien it is necessary not only to trace its origin and development but also to account for them, addressing not only the question 'How did it develop?' but also 'Why?'. This is an issue about which previous writers have said little, other than to suggest that an invasion may have been responsible for its appearance in this part of France. It is now time to bring the fortified sites back into the discussion. Though they first appear before the Peu-Richardien pottery they fall into disuse at about the same time, and the geographical congruence of fortified sites and pottery is such as to suggest that they are parts of the same phenomenon, and that each can throw light on the other.

The late neolithic settlement hierarchy of WestCentral France is poorly understood. It is, however, unlikely that the fortified site was the most common type of settlement during that period. Smaller late neolithic settlements may be represented by the scatters of flints and pottery frequently turned up by the plough, but PeuRichardien decorated ware is only very rarely encountered in such contexts. It is at the fortified sites that most of the characteristic pottery has been found. The few unenclosed sites which have yielded Peu-Richardien pottery have in most cases, as at La Sauzaie and La Garenne, been shown like them to have been substantial settlements, if undefended. Ritual deposits in tombs are the third principal context in which the characteristic decorated ware is found. Future research may show this pottery to be present at a wider range of sites, but at the moment it seems to be confined to the major settlements and to some ritual contexts. The quality of the pottery and the amount of time which must have been spent on its decoration support the idea that it was in some sense a luxury or prestige ware, perhaps manufactured by specialist potters at a few centres and traded around between sites. The proximity of almost all the major late neolithic settlements to navigable waterways would have encouraged and facilitated such trade.

A further indication of the social organization of the late neolithic is provided by the appearance and location of the fortified sites. The scale of the defensive works demonstrates that competition existed between settlements or social groups which made it necessary for the inhabitants to surround themselves with elaborate and no doubt costly fortifications. Recent work has suggested that the object of the competition may have been the control of wet lowland pasture, a critical resource in this rather dry landscape, but one limited in area and occurrence, and which probably became available in any quantity only after $3000 \mathrm{bc}$, when sea-level began to fall (Scarre, 1982 ). The first fortified sites appeared within a few centuries of this event (at c. $2800 \mathrm{bc}$ ); the rapidity of the response is an indication of the high demand for the newly available grazing. These seem to be the particular local circumstances which were responsible for the foundation of many of the late neolithic fortified sites of West-Central France (Scarre, $1982 ; 1983$ ).

It is possible that such conditions of social and economic stress led to the development of a more stratified society in the early third millennium bc, but it must be admitted that there is little direct evidence for this. The elaborate defensive works imply the existence of a co-ordinating authority, but it need not have been strongly hierarchical. The decorated Peu-Richardien pottery may have been the prestige ware of a ruling élite, but this is difficult to demonstrate, and there are few other items found at the fortified sites which could be 
regarded as prestige objects. The burial evidence is of little help. The territorial-type spacing of the fortified sites in some areas does, however, suggest that they may have performed at least some of the functions of central places in territories of a social or economic nature. Cases where a single fortified site appears to dominate a limestone 'island' or 'promontory' surrounded by marshland are particularly suggestive in this regard (e.g. the site of Le Haut du Tertre on the 'promontory' of Velluire, or La
Maison de la Chaume on the nearly 'island' of Vix: Marsac \& Scarre, 1979, Fig. 24). Analyses of these kinds are hindered, however, by the present difficulty of demonstrating which of the settlements were in contemporary occupation. Nonetheless, the potential offered by these sites and pottery styles for the study of the social organization of the period is clearly substantial and this, it is hoped, is the direction which future research on the PeuRichardien will take.

Table 1

Radiocarbon dates for 'Matignons' and 'Peu-Richardien' material

I. Matignons

* Semussac

* Semussac

* Les Matignons camp I

*Les Matignons camp I
Gif- 1718

Gif -474

Gif-

Gif-
$2770 \pm$ I $10 \mathrm{bc}$ $2740 \pm 250 \mathrm{bc}$ $2725 \pm \mathrm{I} 60 \mathrm{bc}$ $25 \circ 5 \pm \mathrm{I} 60 \mathrm{bc}$
2. Saintonge Peu-Richardien, early phase
Le Garenne
Gif-3 3
$2840 \pm 250$ bc
Le Garenne
Gif- 4 I 7
26 ro $\pm 250 \mathrm{bc}$
La Sauzaie
Gif-I 557
$255^{\circ} \pm 140 \mathrm{bc}$

3. Saintonge Peu-Richardien, later phase

$\begin{array}{lll}\text { La Sauzaie } & \text { Gif-2608 } & 2460 \pm 120 \mathrm{bc} \\ \text { *Semussac } & \text { Gif-1717 } & 2450 \pm 135 \mathrm{bc} \\ \text { La Sauzaie } & \text { Gif-2610 } & 2410 \pm 120 \mathrm{bc} \\ \text { *Semussac } & \text { Gif-475 } & 2300 \pm 250 \mathrm{bc} \\ \text { Ors } & \text { Gif-1330 } & 2130 \pm 120 \mathrm{bc} \\ \text { Ors } & \text { Gif-1329 } & 2120 \pm \text { 120 bc } \\ \text { *Semussac } & \text { Gif-1719 } & 2120 \pm 110 \mathrm{bc}\end{array}$

(*denotes ditched enclosure)
4. Peu-Richardien, Moulin-de-Vent style

*Biard Gif- 239 I $\pm \mathrm{r} 37 \mathrm{bc}$

Doubtful dates

5. Peu-Richardien, Roanne style

$\begin{array}{lll}\text { Roanne } & \text { Gif-782 } & \text { I goo } \pm \text { I35 bc } \\ \text { Roanne } & \text { Gif-783 } & \text { I } 750 \pm \text { I35 bc }\end{array}$

6. Poitou Peu-Richardien

*Champ Durand Gif-3675 2160 \pm i $30 \mathrm{bc}$

Information from Mohen $197 \mathrm{I}$, with additions from Burnez r976 (I962), 373, Pautreau et al,, r974 (La Sauzaie) and Joussaume, i 980 (Champ Durand). Several of the dates have large standard error quotes which limit their value. It is for this reason difficult to use the La Garenne determinations as evidence that the Saintonge Peu-Richardien began early in the $3^{\text {rd millennium. The }}$ Roanne dates are almost certainly several centuries too late and probably contaminated. The Champ Durand determination may not relate to Peu-Richardien material.

\section{BIBLIOGRAPHY}

Bergougnan, D. \& J.-P. MOHEN. 1980. L'histoire du camp néolithique de Semussac, Dossiers de l'archéologie, 42, $75^{-9}$.

BRESSON, P. \& B. GADE. 1980. Restes humains et poteries peu-richardiennes dans le fossé de pente à Champ Durand, commune de Nieul-sur-1'Autize (Vendée), Bulletin $d u$ Groupe Vendéen d'Etudes Préhistoriques, 4, 15-24.

BurNez, c. 1956. Quelques réflexions sur la civilisation de Peu-Richard, Bull. Soc. Préhist. Française, 53, 38 I-90.

1965. La station de Soubérac à Gensac-la-Pallue (Charente), Bull. Soc. Préhist. Française, 62, 289-315.

1976. Le Néolithique et le Chalcolithique dans le Centre-Onest de la France. Mémoire de la Société Préhistorique Française 12 (Paris).

burnez, c. H. CASE. 1966. Les Camps néolithiques des Matignons à Juillac-le-Coq (Charente), Gallia Préhistoire, 9, I 3 I -245 .
BURNEz, c. \& R. FAÇON. 1957. Le terrier de Biard (commune de Segonzac, Charente). Bull. Soc. Préhist. Française, 54, $77^{\circ-4}$

BURNEZ, C. \& J. MOREL. 1965. Contribution à la connaissance de la céramique préhistorique de la Saintonge, Bull. Soc. Préhist. Française, 62, 555-66.

CLouet, м. 1928. L'outillage de la station de Moulin-de-Vent (Montils, Charente-Inférieure), Association Française pour l'Avancement des Sciences (La Rochelle), 445-7.

COFFYN, A. 1960. La station de Roanne, commune de Villegouge (Gironde). Bull. Soc. Préhist. Française, 57, 7 I 3-25.

1965. Stratigraphie de la station de Roanne à Villegouge (Gironde), Actes du XXe Congrès des Sociétés Savantes du Centre-Ouest, 95-102.

COFFYN, A. \& DUCASSE, B. 1962. La civilisation de Peu-Richard dans son expansion méridionale, Reque Historique et Archéologique du Libournais, $105, \mathrm{I}-\mathrm{I} 2$. 
Colle, J.-R. 1957. Simples remarques sur le Néolithique charentaise, Bull. Soc. Préhist. Française, 54, i 28-33.

1965. Une nouvelle station peu-richardienne, Bull. Soc. Préhist. Française, 62, CLI-CLIII.

DASSIE, J. 1978. Manuel d'archéologie aérienne (Paris).

DREWETT, P. 1977. The excavation of a neolithic causewayed enclosure on Offham Hill, East Sussex, 1976. Proc. Prehist. Soc., XLIII, $201-42$.

ESChaSSERIaUX, E. 1882. Le camp néolithique du Peurichard (Charente-Inférieure), Matériaux, 18, 505-19.

1884. Le camp néolithique du Peurichard (CharenteInférieure). Recueil des Actes de la Commission des Sites et Monuments Historiques de la Charente-Inférieure et Société d'Archéologie de Saintes, 3, 191-215.

Germond, G. I980. Inventaire des Mégalithes de la France, 6. Deux-Sèves (Paris).

Gulllien, y. 1968. Circonscription de Poitou-Charentes, Gallia Préhistoire, II, 31 I-35.

joussaume, R. 1980. Champ Durand à Nieul-sur-l'Autize (Vendée). Site préhistorique fortifié (La Roche-sur-Yon: Groupe Vendéen d'Etudes Préhistoriques).

r981. Le Néolithique de l'Aunis et du Poitou Occidental dans son Cadre Atlantique (Rennes).

MARSAC, M., D. RILEY \& C. SCARRE. 1982. Recent discoveries of possible neolithic long mounds in Western France and their British parallels, Aerial Archaeology, 8, 1-16.

MARSAC, M. C. SCARRE. I979. Recent discoveries of neolithic ditched camps in West-Central France. Aerial Archaeology $4,37-57$.

\section{Book Chronicle continued from p. 14}

Acquarossa Vol. II, Part 2: The cooking stands by Charlotte Scheffer. Skrifter utgivna av Svenska Institutet i Rom, xxxv111: 1I, 2. Stockholm: Svenska Institutet i Rom, 1983.90 pp., 118 figs. 180 SKr.

Acquarossa Vol. IV: Early Etruscan akroteria from Acquarossa and Poggio Civitate (Murlo) by Eva Rystedt. Skrifter utgivna av Svenska institutet i Rom, xxxvm:1v. Stockholm: Srenska Institutet $i$ Rom, 1983. 166 pp.;, 117 figs., 31 pls. $280 \mathrm{Skr}$.

The earliest wheeled transport. From the Atlantic Coast to the Caspian Sea by Stuart Piggott. London: Thames $\&$ Hudson. 1983. 272 pp., 142 illus. $£ 20.00$.

The Mimbres People: ancient Pueblo painters of the American southwest by Steven A. Leblanc. New aspects of Antiquity series. London: Thames $\varpi^{\circ} \mathrm{Hud}$ son, 1983.184 pp., 29 figs., 85 b/w pls., 15 colour pls. $£ 18.00$

The farming of prehistoric Britain by P. J. Fowler. Cambridge: University Press, 1983. 256 pp., 8 pls., 60 figs. $€ 7.50$.

Bison kills and bone counts: decision making by Ancient Hunters by John D. Speth. Prehistoric archaeology and ecology series. Chicago and London: University of Chicago Press, 1983. 254 pp., 60 figs. f.16.00
Mercer, R. I980. Hambledon Hill. A neolithic landscape (Edinburgh).

MOHEN, J.-P. 1967. Notes préliminaires à propos des fouilles du camp néolithique de 'Chez-Reine', commune de Semussac (Charente-Maritime). Bull. Soc. Préhist. Française, 64, $460-500$.

1971. Datations par $\mathrm{C}_{14}$ du Néolithique saintongeais, Mémoires de la Société Archéologique et Historique de la Charente $3 \mathrm{II}-4$.

1973. Les remparts néolithiques de Semussac (CharenteMaritime), Recueil de la Société d'Archéologie et d'Histoire de la Charente-Maritime, 25, 5-9.

Nougrer, L.-R. I953. La céramique 'pseudo-oculée' du PeuRichard et son contexte archéologique, Congrès Préhistorique de France XVIc Session, 463-93.

PAUTREAU, 1.-P. et al. 1974. L'habitat peu-richardien de la Sauzaie, commune de Soubise (Charente-Maritime). Fouille de sauvetage. Premiers résultats (Poitiers).

RIQUET, R. I953. Les styles céramiques Néo-Enéolithiques des pays de l'Ouest, Bull. Soc. Préhist. Française, 50, 407-22.

SCARre, C. 1980. Neolithic Camps around the Marais Poitevin, Current Archaeology, 72, 23-5.

1982. Settlement patterns and landscape change: the late neolithic and the bronze age of the Marais Poitevin area of Western France, Proc. Prehist. Soc., xLviII, 53-73.

1983. The Neolithic of West-Central France, in (ed.) C. Scarre, Ancient France 6000-2000 bc (Edinburgh), $223-70$.

U.R.A. I 2 (Unité de Recherche Archéologique No. 12 ), 1977. Les fouilles protohistoriques dans la vallée de l'ilisne, 5 .

Roman Britain by T. W. Potter, London: British Museum Publications, 1983. 72 pp., many colour illus. £4.95.

Assyrian Sculpture by Julian Reade. London: British Museum Publications, 1983. 72 pp., many colour illus. f.4.95.

Clocks and watches by Hugh Tait. London: British Museum Publications, 1983.72 pp., many colour illus. f4.95.

Egyptian Sculpture by T. G. H. James \& W. V. Davies. London: British Museum Publications, 1983. 72 pp., many colour illus. $€ 4.95$.

Village and farmstead: a history of settlement in rural England by Christopher Taylor. London: George Philip, 1983. 254 pp., 101 illus. £10.95.

Those who have vanished: an introduction to prehistory by Ronald L. Wallace. Homewood, Illinois: Dorsey Press, 1983. 228 pp., many illus. \$24.95.

Primitivas religiones ibericas. Tomo II. Religiones preromanes by J. M. Blazquez. Madrid: Ediciones Cristiandad, 1983. 556 pp., 186 figs.

Rome's North West frontier: the Antonine Wall by William Hanson \& Gordon Maxwell. Edinburgh: University Press, 1983. 248 pp., illus. £.17.50.

continued on p. 32 

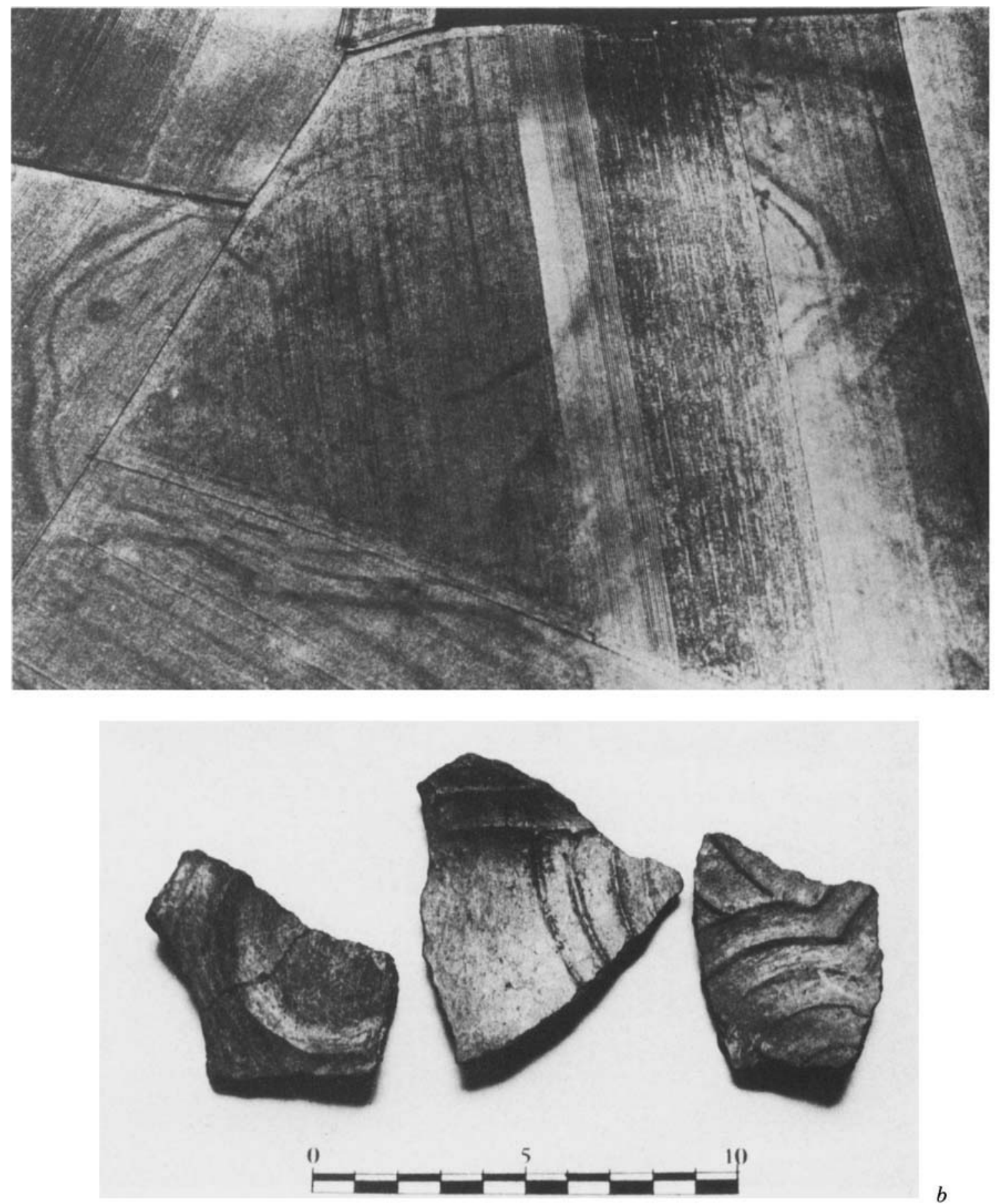

PLATEV: A CENTURY OF RESEARCH ON THE PEU-RICHARDIEN

(a) Aerial view of Peu-Richard from the E. Several preziously unnoticed 'pince de crabe' entrance-works clearly visible. (b) Peu-Richardien relief-decorated pottery of the 'Roanne' vanety, now in Musée de Libourne. 'Moulin-de-Vent' pottery is similar 